\title{
Educational Policy and Leadership to Improve Democratic Citizenship Education
}

\author{
Eve Eisenschmidt, Triin Lauri and Reet Sillavee
}

\section{1 \\ Introduction}

In the debates on educational policy, rather than actually understanding what is the intention behind the policy, the participants usually focus on how well a set of regulations is implemented. Instead of understanding how schools are coping with often contradictory policy demands, immediate results and following orders is expected (Ball, Maguire, \& Braun, 2012). To educate proactive and responsible democratic citizens, educational leaders and teachers should first understand how a policy is developed. Teachers and leaders should be aware what are the possibilities to actively participate in policy development, who are the most relevant stakeholders, and what is the connection between international trends and local needs. What is needed is the understanding that school, next to families, is a very important development environment for educating active citizens - educators have the responsibility to lead the students in understanding their opportunities and obligations as citizens.

Europe and its member states need a strong democracy, an inclusive society, and active citizens (Veugelers, de Groot, \& Stolk, 2017). Citizenship education in teacher education and educational studies, particularly with a focus on democracy and intercultural dialogue, has not received much attention (Veugelers, 2011). Teaching Common Values (TCV) is fairly important in half of the EU member states, but compared to other topics and subject areas, attention given to TCV is still lacking (Veugelers et al., 2017, p. 9). Therefore, every member state should consider how to integrate citizenship education more thoroughly into school curriculum.

In Estonian context, some important milestones should be considered in the education of future teachers and leaders regarding citizenship education. Since 1996, schools are encouraged to develop their own curricula within the national core curriculum framework (i.e. school-based curriculum development) (Estonian Government, 1996). This is considered as a way of increasing school autonomy and democracy in education. Like many reforms in transitional countries, including Estonia, school-based curriculum development 
was adopted before schools acquired the necessary competence and before teachers were ready to take a proactive approach to curriculum development and use their autonomy. This means also that educational system was decentralised and principles of shared leadership and engagement of all teachers in school development were introduced, but not implemented. Furthermore, policy guidelines for professional school leaders emphasise team building and delegation of responsibilities and duties (Innove, 2015, p. 8), but how to do that, was unclear to teachers and leaders. Although we state that transition phase is over, teachers and school leaders still need to develop proactive attitude and knowledge of how to develop school curriculum, how to work with local community and involve parents into discussions, so that the teachers and school leaders will become policy developers on both local and school level. For that they should also have a wider perspective and understanding of global trends.

Content-wise, it seems that developments are several steps ahead. The national curriculum for basic schools and upper-secondary schools from 2011 declares that schools shall create conditions for the balanced development of pupils with a variety of abilities, for self-actualization, and for shaping a knowledge-based worldview. Every student should have a strong basic education, be capable of integrating into society, and be able to contribute to sustainable social, cultural, economic and ecological development of Estonian society. The Estonian Lifelong Learning Strategy 2020 (Estonian Ministry of Education and Research, Estoninan Cooperation Assembly, \& Estonian Education Forum, 2014a, p. 5) lists under the success factors of current Estonian education alternative approaches to education as a way of making the formal education system more flexible, innovative and diverse for all learners. The strategy emphasises that values like democracy and tolerance are strongly needed to develop an inclusive education system and focus on the development of every learner's capabilities.

Master's level course Educational Policy and School Leadership sets off in the above- mentioned conditions. The course is designed so that learning about the changes and developments in education go in parallel with the changes in governance of education, including the effects on labour market, and trends in citizenship development as well as in social inclusion and tolerance. The main outcome is on the one hand, a broader understanding of wider paradigmatic shift in educational governance and educational policy making, and on the other hand, an understanding of what are the responsibilities and opportunities of each individual to contribute to policy making.

Three main topics form the course outline: (1) European context and comparative perspective on national educational policy; (2) educational governance and policy making, (3) influence of social change and globalization on 
policy development. Each of the themes are covered by both theoretical lectures with teachers' key notes or reversed classroom method, and a seminar with practical assignments and self-analyses that help to reinforce new knowledge and beliefs. The balance between theory and practice help to shape a proactive attitude in students towards development and change. A proactive student becomes a proactive teacher or school leader who helps students to become active citizens. The following gives an overview of main concepts which are the basis for topics of the course.

Theoretical Background

\subsection{Comparative Perspective on National Educational Policy}

Comparative perspective helps to learn from other educational systems, at the same time avoiding borrowing from other systems. Researchers have cautioned against the direct transplant of educational "solutions" from one context to another (Crossley \& Watson, 2003). There are very big differences between countries, systems and contexts, and the context matters often much more than policy makers realize, and de-contextualized policy borrowing is not without its risks (Harris \& Jones, 2015). It could be a simple solution to get familiar with the best performing countries based on some international surveys (e.g. PISA, TIMSS, ICCS, etc.) and adapt policies and curricula from these systems. The experts working in comparative education warn that policies and practices should not be readily transferred from one context to another and they advise against transnational policy borrowing (Steiner-Khamsi, 2014). Harris and Jones (2015) point to the fact that there is a substantial international literature that outlines a positive relationship between school leadership and organizational performance and improving the quality of leadership has been a priority for educational policy makers in many countries for many years. Still, every country or system should find their solutions which suit the best in their particular context. The field of comparative education has demonstrated again and again that context plays an essential role in interpreting educational outcomes and effects (ibid., p. 316).

Steiner-Khamsi (2014, p. 154) compares two types of questions in policy borrowing research - normative versus analytical questions. Normative questions are such as "Which are the 'best practices' that should be adopted?"; "How can 'best practices' be effectively disseminated?"; "What has been improved as a result of policy borrowing?". Analytical questions are such as "Why and whose practices are considered as 'best practices'?"; "Under which conditions is dissemination of a practice likely to occur?"; "Who benefits, who loses in 
the act of lesson drawing?". When studying different educational systems and practices, both types of questions should be included. Seeking for just "best practices" is very common for practitioners without being aware of broader context and external factors. During the teacher education or leadership programmes, the participants should develop an understanding about how national educational systems work and why one or the other system is built the way it is built. Even more so, teachers and school leaders should understand that the same practices may yield different results, even for organisations that are part of the same national education system, if the contextual factors are different.

\subsection{Educational Governance and Policy-Making}

According to Lipsky's (2010) well-known argument, a policy is made in the daily encounters between street-level bureaucracy and citizens. The same holds in case of education policy, where school leaders and teachers (i.e. street-level bureaucrats) are important stakeholders in educational governance. Therefore, it is important that they understand the main changes in educational governance. This part of the course explains the underlying logic of the changes in educational governance, the changing meaning of public education, the importance and modes of citizenship education, and the relationship between welfare state and educational inequality.

The paradigm shift from government to governance is widely analyzed phenomenon in political science. It refers to different stakeholders participating in governing to cope with the ever-increasing complexities of governing tasks. According to Rhodes (1997), governance is self-organizing, inter-organizational network characterized by interdependence, resource-exchange, rules of the game, and significant autonomy from the state. In focusing on the paradigmatic shift from government to governance in educational policy and consequent reforms, we aim to emphasize, first, the changing role of government in (educational) governing; second, the increasing challenge to cope with more active stakeholders (such as parents - for instance, by giving them more freedom in choosing the school for their child, i.e. school choice) and third, diversity in educational supply on the one side and educational equity on the other side. In public policy, the doctrine of "new governance" is emerging. Far from being unanimous, the main challenge of the doctrines under this heading is the search for a new governing mode adequate for increasing social and cultural diversity, and acknowledging the social embeddedness of individuals' choices (Bevir, 2010). The main characteristics of these ideal-typical governing modes in educational policy and school choice policy in particular are explained (see Table 7.1). 
TABLE 7.1 The main characteristics of ideal-typical governing modes in educational policy and school choice (Source: Lauri, 2013)

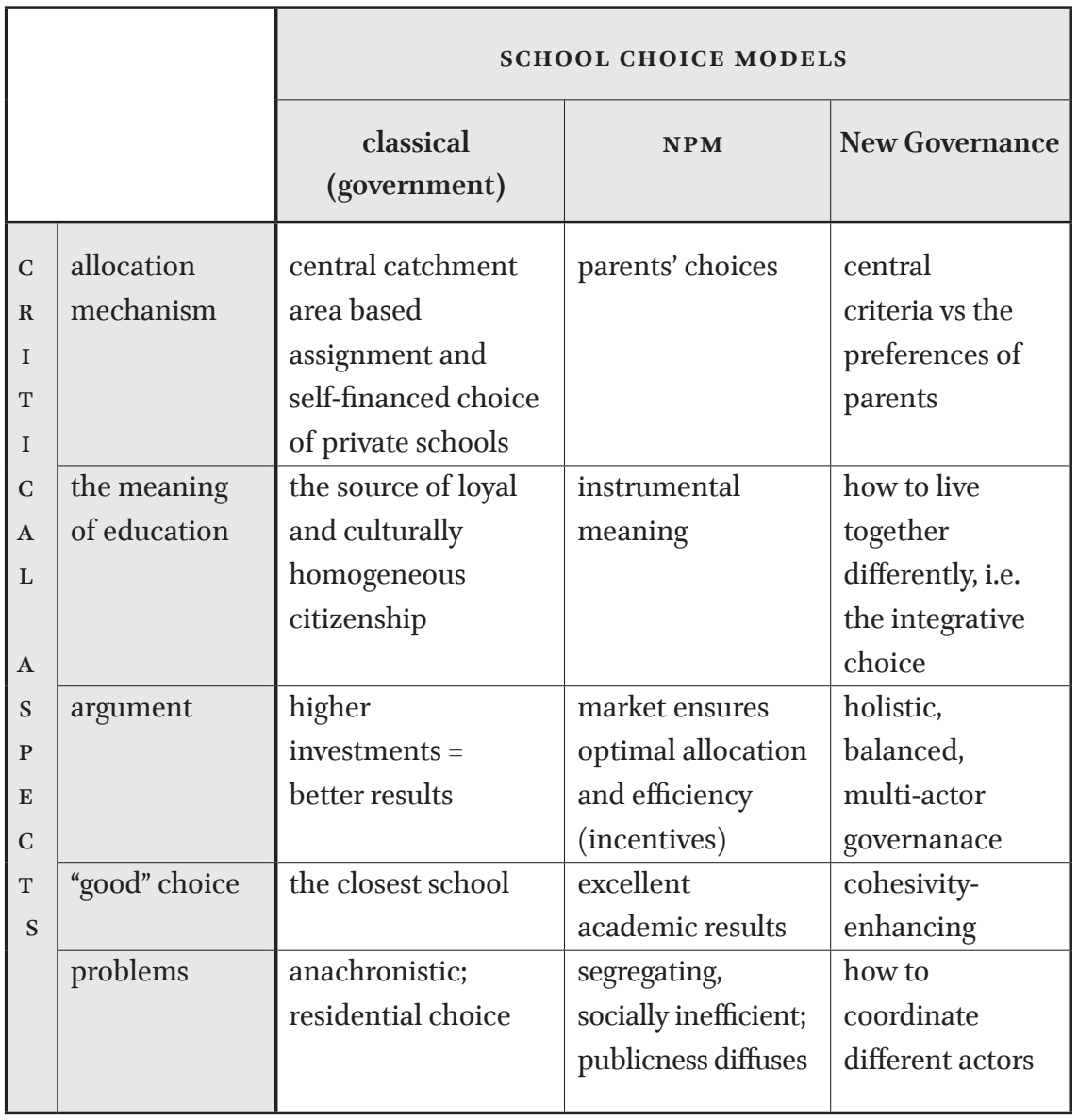

According to New Public Management (NPM), the solution to the inefficiency of classical governing is hoped to be found in the market solutions and/ or privatization (Hood, 1991). In cases where handing service delivery over to the market is not possible, the creation of a market within the public service is preferred. The main slogan of NPM - "choice, diversity, market and competition" - presumes that the market enables all parties to take part in a transaction to satisfy their needs, as the market empowers people to be aware of the "market situation" and to take responsibility for their choices. The ever-more flexible options from the demand side (school choice instead of catchmentbased assignments, for instance) are believed to allow suppliers to react to diverse social needs (Lauri, 2013). Paradoxically, the hoped ability of NPM to 
respond to the diverse needs fails, and the drive towards efficiency leads to a narrower approach to public service and stratified service delivery (Bevir, 2010; Lauri, 2013). While there are countries where NPM-led initiatives have been a clear political choice, in many countries, the principles of NPM emerge to the political agenda and/or pubic services more covertly (Lauri \& Põder, 2013). In Estonia, the competitive entrance of some schools in Tallinn with entrance tests and prep-schooling is one of the examples of this hidden and covert route of NPM-led policies. While this phenomenon is highly criticized by scientists and its detrimental social effects have been revealed, this problem of educational inequality has been rather neglected by policy-makers.

The New Governance developments are hoped to be a more adequate reaction than NPM to hierarchies and market-based inequalities, and better able to respond to contemporary heterogeneity. However, while NPM is a rather coherent doctrine, the concept of governance or New Governance is much more ambivalent and there are several interpretations and variety of initiatives (whole-up and joined-up governance, post-NPM to name some). Still, these varieties of policy initiatives tend to emphasize collaboration, partnership, networks and empowerment instead of competition. As stressed by Bevir (2010), public service has to reflect collaboration and trust, even while being market-based.

The discussion about the potential harm competition-oriented and marketbased solutions in education might cause has motivated scholars (Schütz, Ursprung, \& Wößmann, 2008) to show that equality in educational opportunities is strongly influenced by the institutional set-up of countries education system. Following this literature, Lauri and Põder (2013) and many others have shown that educational efficiency and equity can be complementary (see Figure 7.1). However, this complementarity is very much dependent on the design of educational policy. In other words, the question of how to govern and what are the key characteristics of educational policy is fundamental in terms of educational equity. As shown by Lauri and Põder (2013), there are more or less school choice prone countries that do well in terms of showing good results in both dimensions, educational efficiency and equity. However, there are important criteria which have to be met in order to mitigate the choicecaused harm to equity. The restrictions on schools to "skim the cream" is the most important one among these criteria.

With focusing on the changing meaning and importance of public education, and the essence and quality of civic and citizenship education, our aim is to emphasize that contemporary society is especially demanding in terms of both, education in general and education for social and political participation in particular. Therefore, it becomes crucial to ensure that education is 


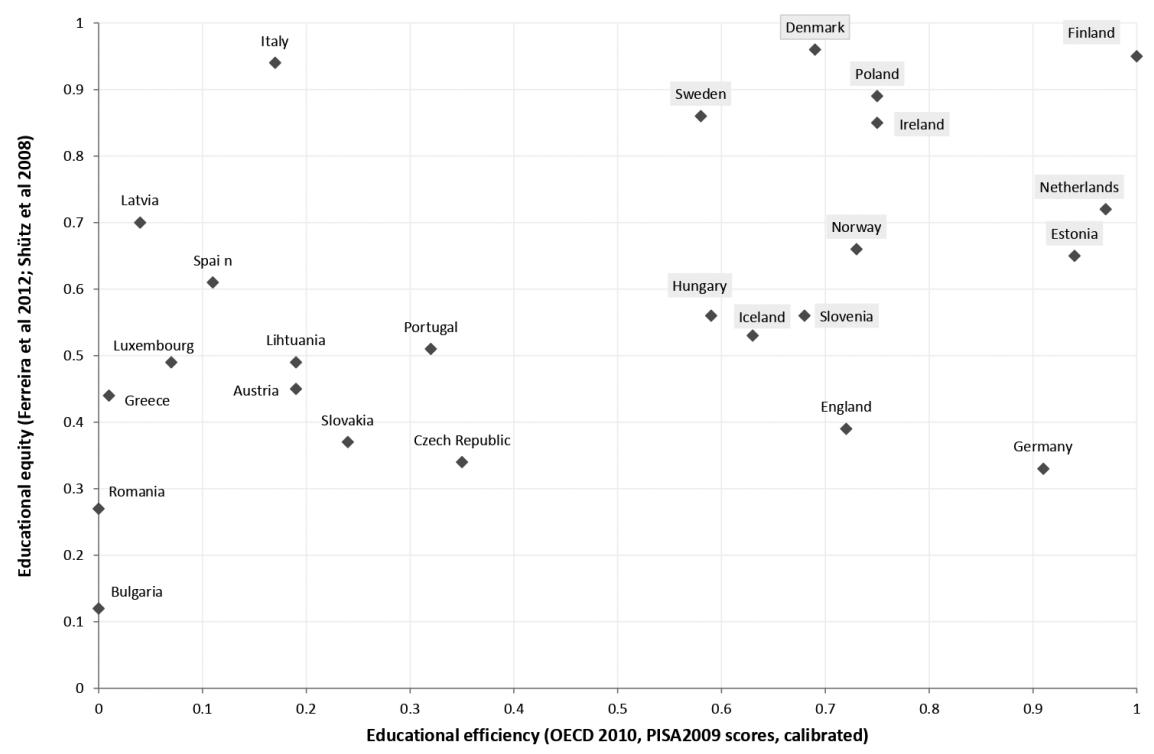

FIGURE 7.1 Efficiency and equity in education (Source: Lauri \& Põder, 2013)

capable of equipping young citizens with knowledge needed to take up new and expanded participation possibilities (Hedtke \& Zimenkova, 2013). However, ideally, a public school should be defined and evaluated by its unique goal - to renew the public by providing the young with the skills, dispositions, and perspectives required to engage with others about their shared interests and common fate (Feinberg, 2012). Yet, just what does it mean to renew the public and to engage with one another? According to Feinberg (2012), general goals of education that is public in the strict sense of the term is to encourage students to act as if everyone had the requisite knowledge and was willing to comply, with the understanding that their act has a communicative value and serves to encourage compliance. This requires a pedagogical strategy and a curriculum where students are treated with respect, and where they learn to air their different views while respecting the views of others. The aim of this module of the course is to introduce educational practices and challenges in providing this publicness by schools. Publicness is defined as a way of talking about the combinations of things, ideas, issues, people, relationships, practices and sites, that have been made public (Newman \& Clarke, 2009). The main challenge for Estonia and stakeholders responsible for civic and citizenship education is the ethnic gap in the educational outcome. More specifically, there are remarkable differences between the educational outcome of students studying in Russian and Estonian language schools and this gap is prevalent across all subjects studied, including civic and citizenship 
(Lauri, Põder, \& Rahnu, 2017). As an inheritance of Soviet era, Estonia have bilingual schools system where Russian speakers and Estonian speakers study in parallel. While there have been many policy initiatives to integrate these two, the distinctive character of school system has remained unchanged and the gap in educational outcomes, political activism and preferences, and even in media usage is reinforced.

Besides the most relevant topics for Estonia, the more general trends and evidence about civic and citizenship education are examined during the course. The main topics covered are, first, salient issues in terms of citizenship enhancement (such as classroom climate, contextual notion of citizenship, socio-economic embeddedness of civic knowledge). This saliency is mostly identified (Knowles, Torney-Purta, \& Barber, 2018) based on international large-scale assessments, such as the International Civics and Citizenship Education Studies (ICCS) arranged by International Association for the Evaluation of Educational Achievement (IEA). These surveys are designed to provide insights to teachers, researchers and educational policy experts, and they are important sources for future policy-making. The second issue covered in this subtopic is devoted to institutional and contextual factors of quality in civic and citizenship education (Toots \& Lauri, 2015). With elaborating on the quality assurance in civic and citizenship education, we show that the quality is affected by the so-called remote social factors, such as level of economic and social human development, public investment in education and type of civic culture, as well as more proximate factors, such as national approaches to civic and citizenship curriculum and teaching, civic activation initiatives at schools and assessment practices. Furthermore, different contexts require different approaches to quality assurance (ibid., 2015), which means policy learning instead of policy borrowing in order to gain from best practices worldwide.

In the subtopic of relationship between welfare regimes and educational inequality, the main concerns are social inequality and educational systems' role in this. There is a long debate in comparative political science literature on the role of educational policy as a social policy (Di Stasio \& Solga, 2017), stemming from the contradicting views on education policies' ability to tackle social inequality. For a quite a long time, educational policy has been neglected in comparative studies on welfare state (Busemeyer \& Nikolai, 2010; Iversen \& Stephens, 2008). The recent paradigmatic turn to socially investing welfare states has contributed to bringing education policy at the forefront of the conceptualization of welfare states. This turn emphasizes the importance of creation, mobilization and preservation of human skills (Garritzmann, Häusermann, Palier, \& Zollinger, 2017) throughout the entire life course in order to address new social risks not met by the so-called old welfare state 
approach. Education has a major role in providing these goals of socially investing policies. However, while the importance of education has indeed become prevalent, the ability of social investment policies to mitigate social inequalities tend to be sometimes overestimated (Solga, 2014), or the frameworks too narrow to capture how to achieve the enhancement of human capital should or how to generate the expected private and social returns to education (Di Stasio \& Solga, 2017). This is not to say that educational inequalities and their reinforcement mechanisms should not be analyzed based on social investment approach, but rather that future research should clarify the relationships between educational investment, educational institutions, and the distribution of life chances in different welfare state and education regimes (ibid., p. 315). Education policies themselves may generate social problems, i.e. instead of being the solution they might be part of the problem.

\subsection{Citizenship and Curriculum Development}

There is always a dilemma to what extent education should respond to labour market needs and needs of society and personal needs of the citizens. OECD is arguing not only for excellence in knowledge, but also for skills, values and attitudes, for new solutions in a rapidly changing world, and for learners' agency enabling them to navigate through a complex and uncertain world (OECD, 2016a). World Economic Forum is demanding better social skills (2016). Social-emotional competences, multiculturalism and values like tolerance, democracy, open-mindedness are getting more and more attention and thus, it is problematic that most schools still focus solely on academic skills (Veugelers et al., 2017). Non-academic and social-emotional skills - such as self-regulation, problem-solving, social awareness, and growth mindset - have a strong impact on academic outcomes and success in the workforce and in society (Stafford-Brizard, 2016).

The Estonian Lifelong Learning Strategy 2020 (Estonian Ministry of Education and Research et al., 2014a) and the strategy document "Wise and active people" (Estonian Ministry of Education and Research, 2014b) both emphasise the so-called "changed" or "new" learning and teaching paradigm as one of the most important presumptions of educational change. It is defined as "learning and teaching paradigm which supports the individual and social development of each learner, including the learning-to-learn skills, creativity and entrepreneurship" (Estonian Ministry of Education and Research et al., 2014a, p. 4). Despite the promotion of student-centred social constructivist instruction by existing policies since 1996, research indicates that these practices are not sufficiently used by Estonian teachers (ibid.). 
The last curriculum reform was initiated with the 2011 national curriculum (revised in 2014) for basic and upper-secondary schools. Both curricula emphasised cross-curricular themes and integration of subjects, and put more stress on key competences. National curriculum includes eight general competences and one of these is social and citizen competence - the ability to become selfactualized; to function as an active, well-informed, helpful and responsible citizen and to support the democratic development of society; to know and follow values and standards in society; to respect the societal diversity, rules of various environments,, and particularities of religions and nations; to engage in cooperation with other people in different situations; to accept differences in people and their values and to take them into account in interaction with people (Estonian Government, 2011a).

In addition to supporting students' self-actualization and self-directedness, changes in the assessment system of students included the introduction of formative assessment in addition to summative assessment. Moreover, to support the development of cooperation competences, the basic school curriculum includes the so-called "creative project" as a way of developing and assessing student's creativity and entrepreneurship while promoting cross-curricular integration (Estonian Government, 2011a). In upper secondary school, it is mandatory for each student to conduct a personal practical or research project. The curriculum for upper secondary school required the development of distinctive school profiles with different study directions (Estonian Government, 2011b). Since the last curriculum reform, many schools offer elective courses or extracurricular activities. The aim of these electives is to support the development of individual interests of the students, but also to integrate learning with everyday life surrounding the school, in order to develop responsiveness towards needs of the society.

The Estonian school system was decentralised in the early 199os, and responsibility for the local school system was devolved on the municipalities (Estonian Parlament, 1992). Estonian school principals have very high levels of autonomy, including the authority to hire and fire staff, negotiate working conditions and job contracts, make decisions about school finances, educational priorities and development plans for the school (Kitsing \& Peterson, 2011). But the most important task is to develop school-based curriculum as a core of education. As every school compiles its own school-based curriculum, then teachers and leaders of schools and kindergartens should have a broad understanding of the national curriculum development, expectations of the society and labour market, and also about different forms of democracy and related intercultural aspects. 
The 6 ECTs module of Education Policy and Leadership is an open course for students in the field of education. The module is recommended for Educational Leadership students who will take a leading role in school curriculum development and create conditions for teachers' professional development.

\subsection{Aims and Outcomes}

The general aim of the module is to create opportunities for analysing how interculturalism and three components of democracy, that is,participation, democratic politics, and democratic society, are displayed in national educational policy and school curriculum. Students will analyse their own values and opportunities as leaders for shaping and implementing educational policy at different levels of educational system to reinforce three components of tolerance: interpersonal relations, tolerance towards different social and cultural groups, and an inclusive society.

\subsection{Objectives of This Module}

Objectives of this module are to create possibilities for:

- understanding different national educational systems, global context (e.g. European Union) and trends of educational policy development;

- evaluating the influence of educational policy on a specific educational institution;

- understanding how global trends and the needs of the society actualise in school curriculum, reinforcing democratic intercultural citizenship education;

- understanding the responsibilities and opportunities of teachers and leaders to participate proactively in policy making process.

This module provides the broader context of education policy and creates a basis for proactive citizenship (see Figure 7.2). The module will address the following questions: what is education policy, how it is formulated at global, international and national levels, and how it affects democratic intercultural citizenship education, especially equality in education. The module also covers key perspectives and concepts in the analysis of education policy at global, European and national levels. Further, the role of global, transnational, and international trends will be also discussed. The case of Estonia will be used as a particular example of national transition.

The students who pass the course should be able to:

- analyse critically EU and global education policy trends and understand their impact on their national educational system from the perspective of democratic intercultural citizenship education; 


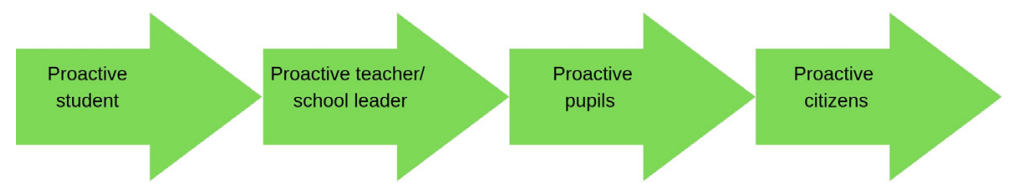

FIGURE 7.2 The process of raising proactive citizens

- understand education policy trends and their connections with the local socio-cultural environment;

- assess the impact and implementation of education policy at a particular level of an educational institution;

- understand their own role and possibilities for proactively participating in implementing education policy;

- continuously monitor education policy initiatives and participate in debates in a proactive manner.

\subsection{Description of the Module and Study Process}

Based on the objectives, the module has three main topics: (1) European context and comparative perspective on national educational policies; (2) educational governance and policy-making; (3) influence of societal changes and globalization in policy development. Learners' attitudes and values, fundamental to build the desired competencies (see Figure 7.3), provide a basis for achieving the learning outcomes.

In the area of European context and comparative perspective on national educational policy, the focus is on: (1) understanding the main characteristics of national educational system; (2) the importance of international organisations in educational policy-making and the Europeanization of education. Students compare national educational systems using Eurydice database, OECD annual reports "Education at the Glance" and other comparative reports such as ICCS. Main challenges are described and students are guided to propose possible policy improvement areas. In this area, the students take a careful look at current trends in education policy at the European as well as global level. Different stakeholders' possible input to policy making is compared, while special attention is given to inclusion through civil society organisations. Managing educational systems, co-operation and competition under different leadership models as well as shaping educational policy, educational reforms and their outcomes is covered.

The area of educational governance and policy-making has three main focal points: (1) the paradigm shift from government to governance in education policy and consequent reforms; (2) the changing meaning and importance of public education and citizenship education; (3) the relationship between welfare regimes and educational inequality. When tackling this topic, the students 


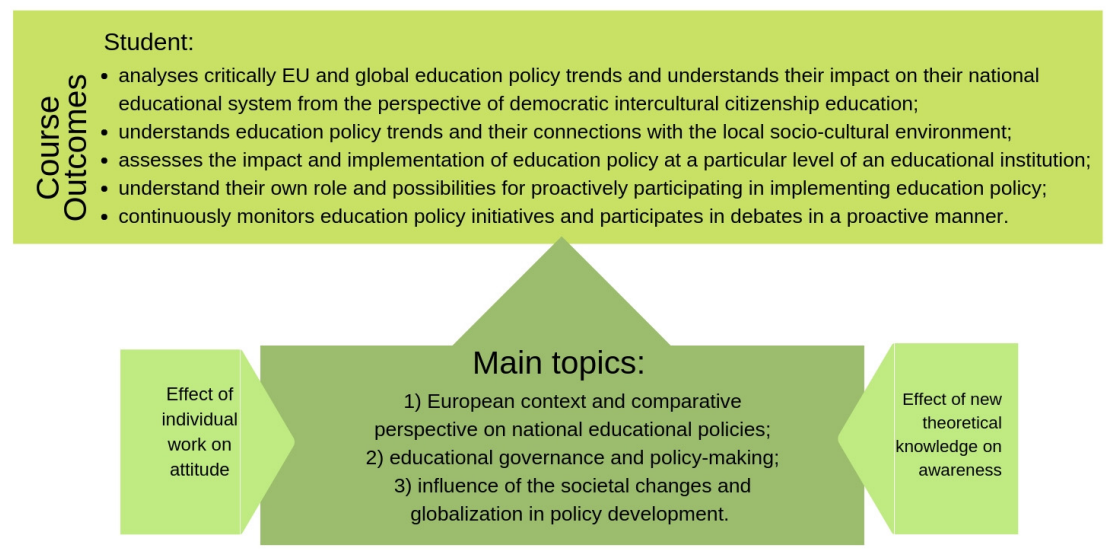

Active citizenship principles. Proactive approach to change.

FIGURE 7.3 Concept of the module

are empowered to critically examine the main challenges related to educational governance in a contemporary, pluralistic frame, and to develop the awareness of related problems and the opportunities to mitigate these problems. The linkages between wider institutional settings of education systems and educational outcomes are emphasized and the changing role of different stakeholders (school leaders, teachers, parents) in them conceptualized.

In the area of the societal change and globalization in policy development, the students are encouraged to analyse national strategies and how strategies influence educational policy and school curriculum. Students will have the opportunity to apply their knowledge in comparative case studies during study-visits to educational institutions and organisations.

Throughout the module, the students analyze international comparative reports and current educational policy topics, and evaluate the impact of policy issues on educational institutions. Special focus is on the analysis of policy design process and how interest groups are involved in them. Important part of the independent work is an interview with an active shaper of educational policy outside of the formal educational system (NGOS, public authorities, politicians, etc.). To support proactivity of the future leaders, short videos are created by the students. Current problems in education, with the focus on democratic intercultural citizenship education are highlighted and possible solutions are proposed. Students should prepare for topics discussed in the class by reading literature and fulfilling individual tasks (see Table 7.2).

Course is organised as a two-month intensive course. Every week, there is one 6-8-hour day where lectures and seminars are tightly integrated. For every class, the students have independent reading and individual or group works to 


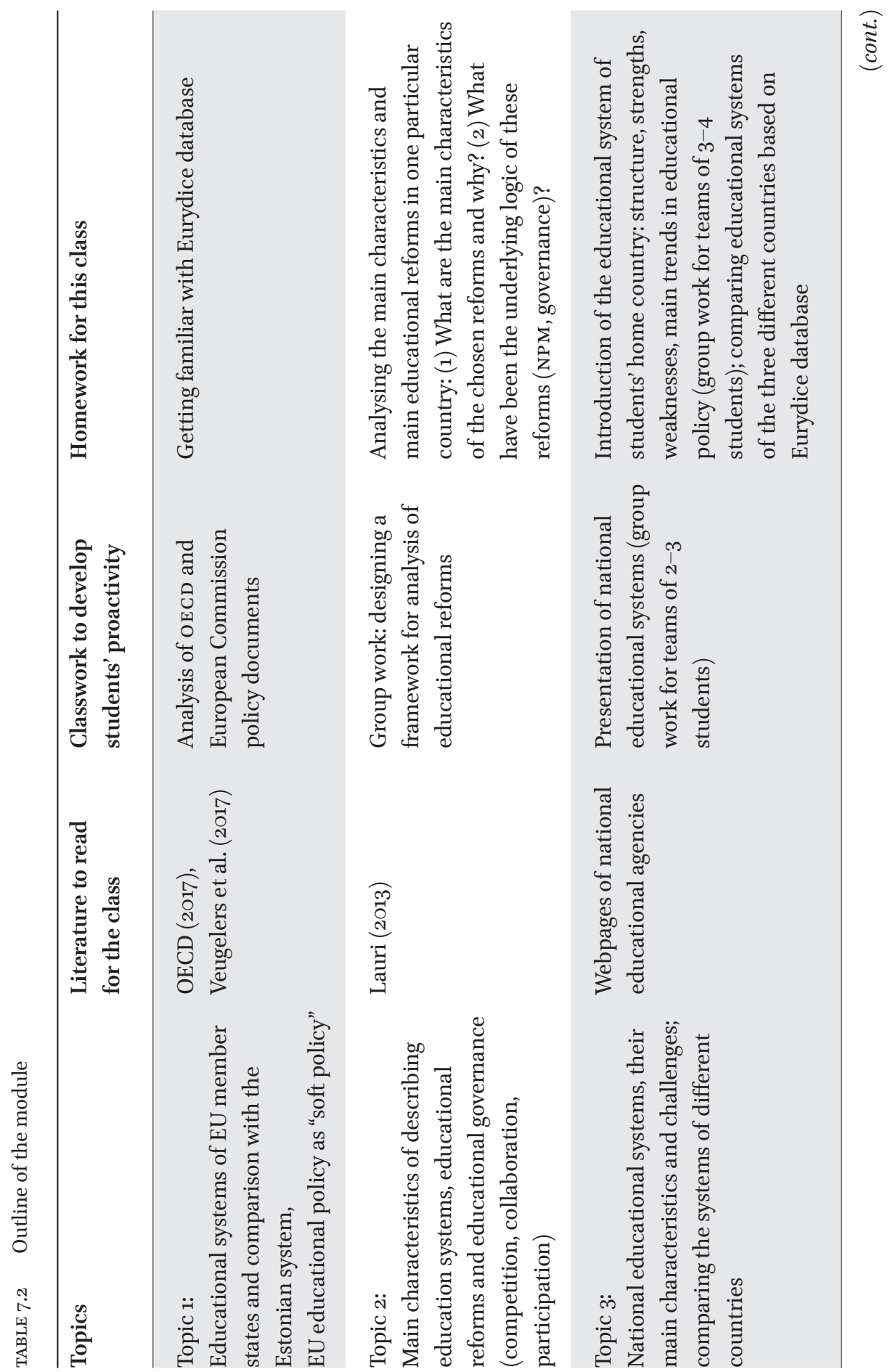




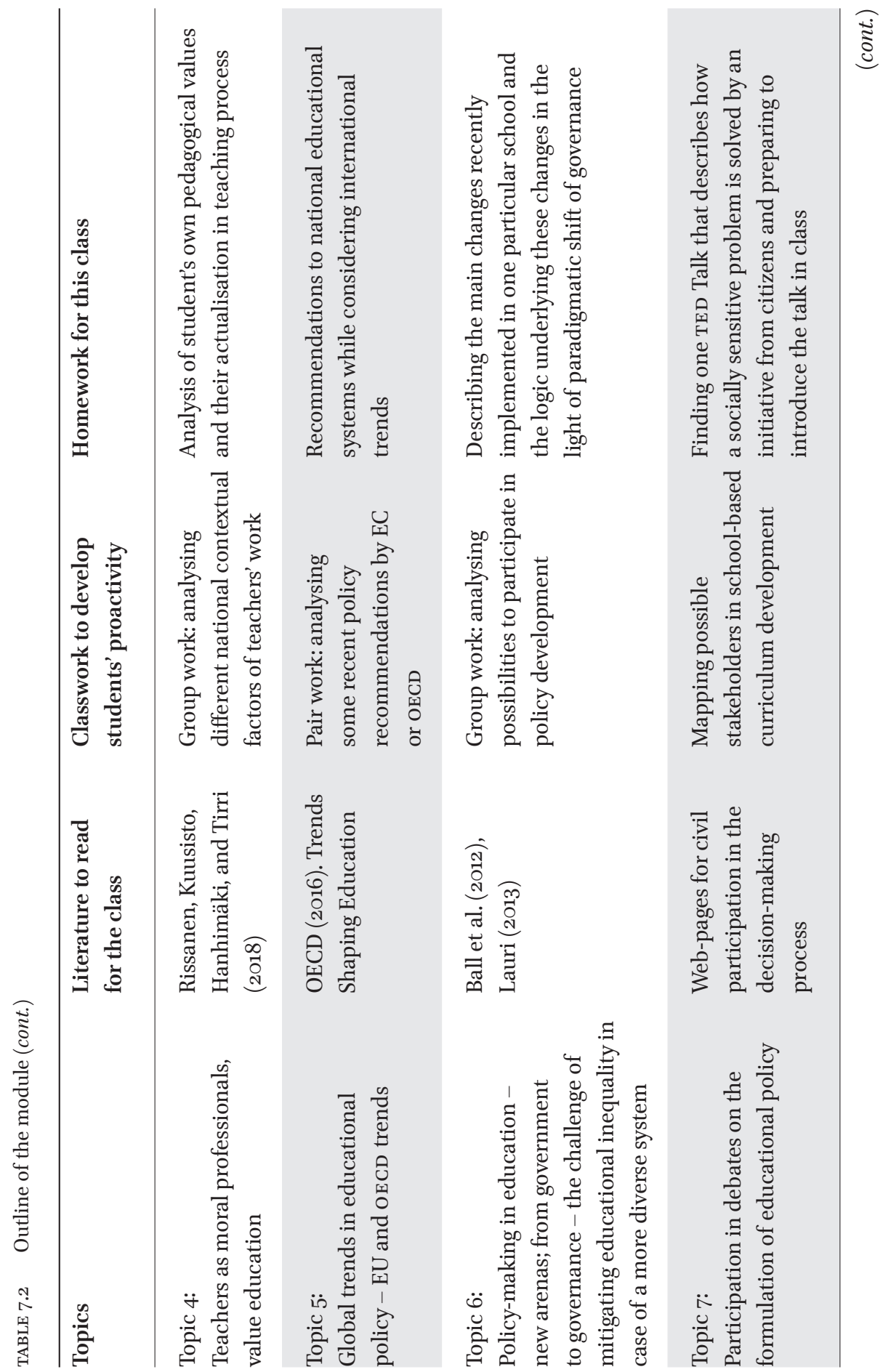




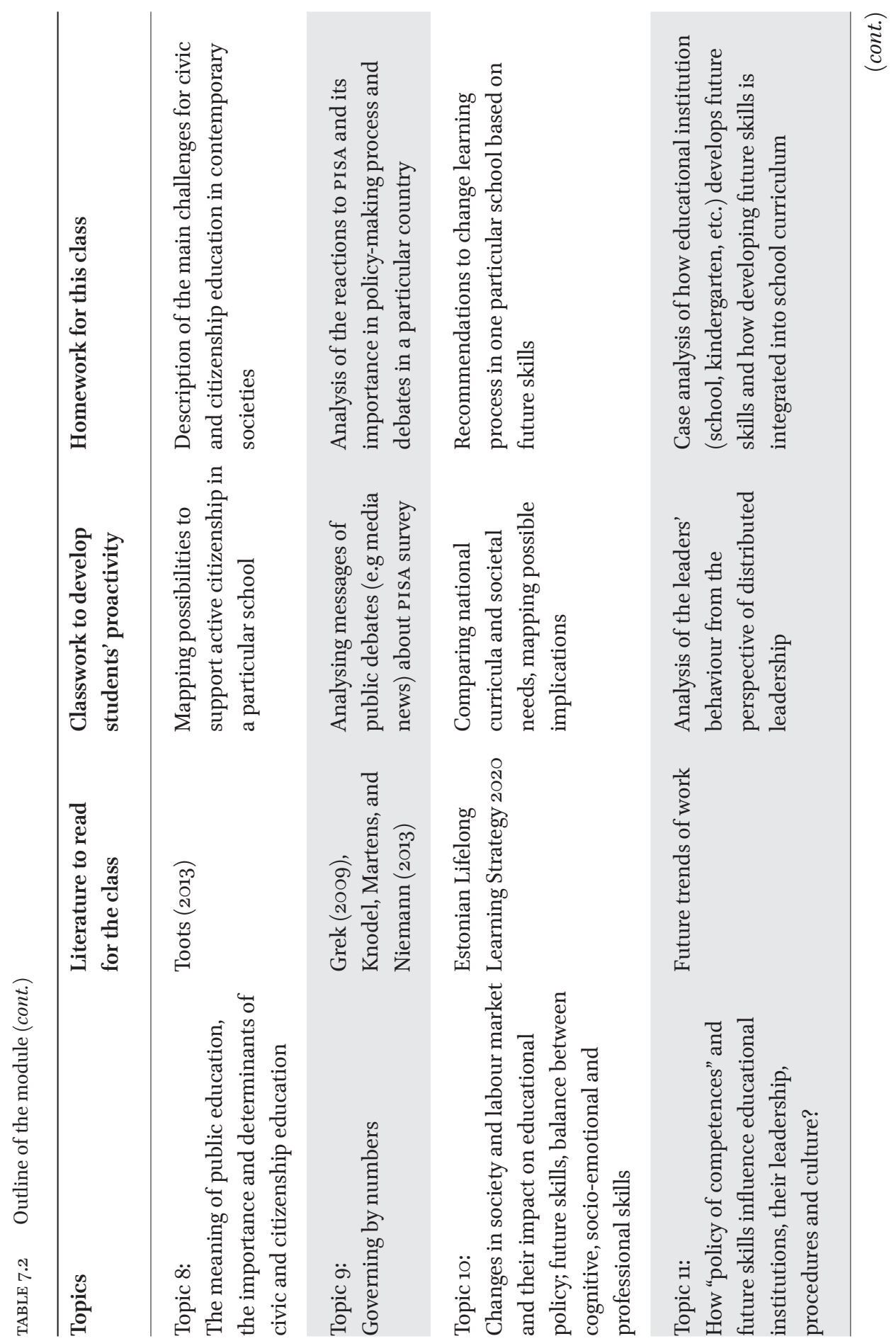




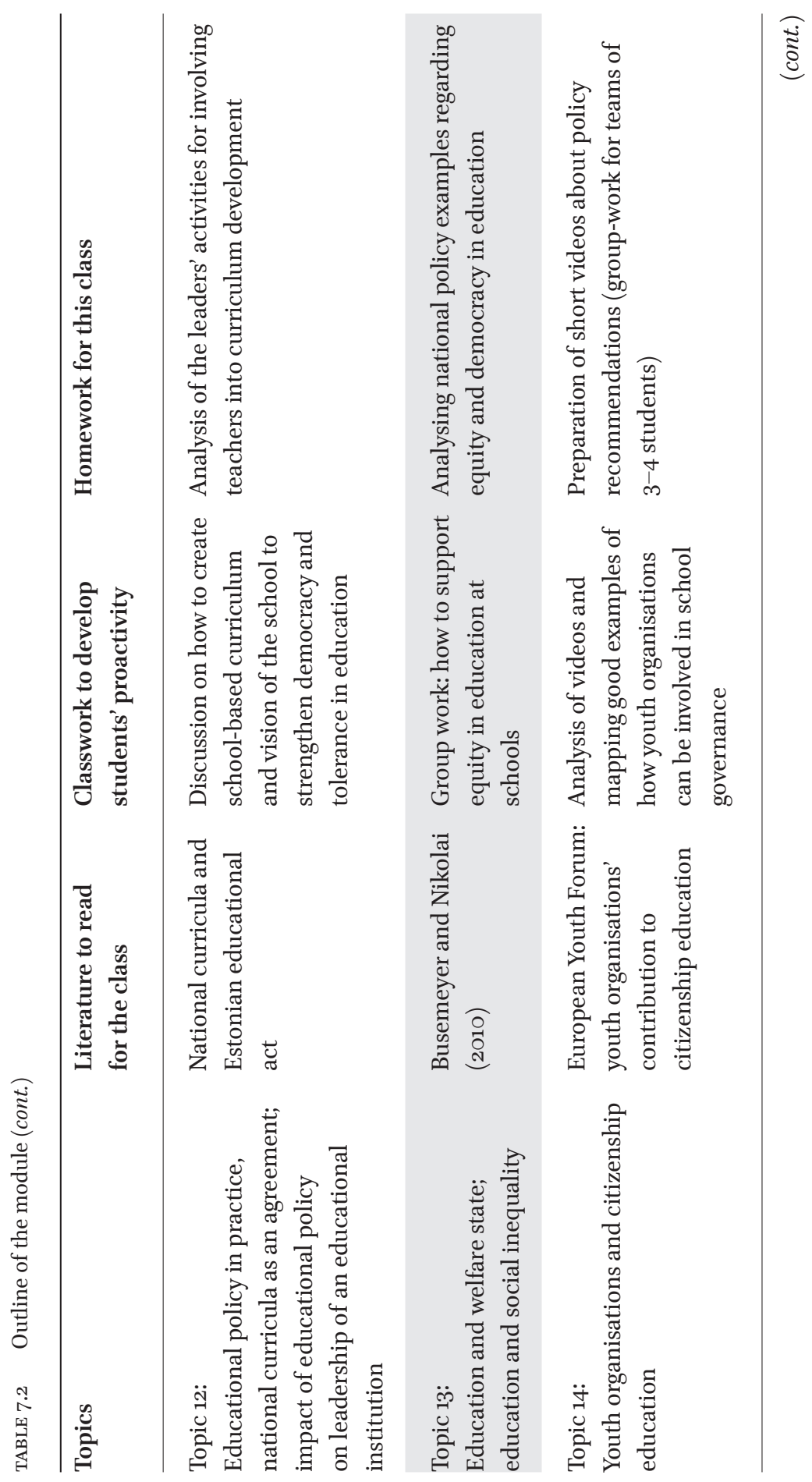




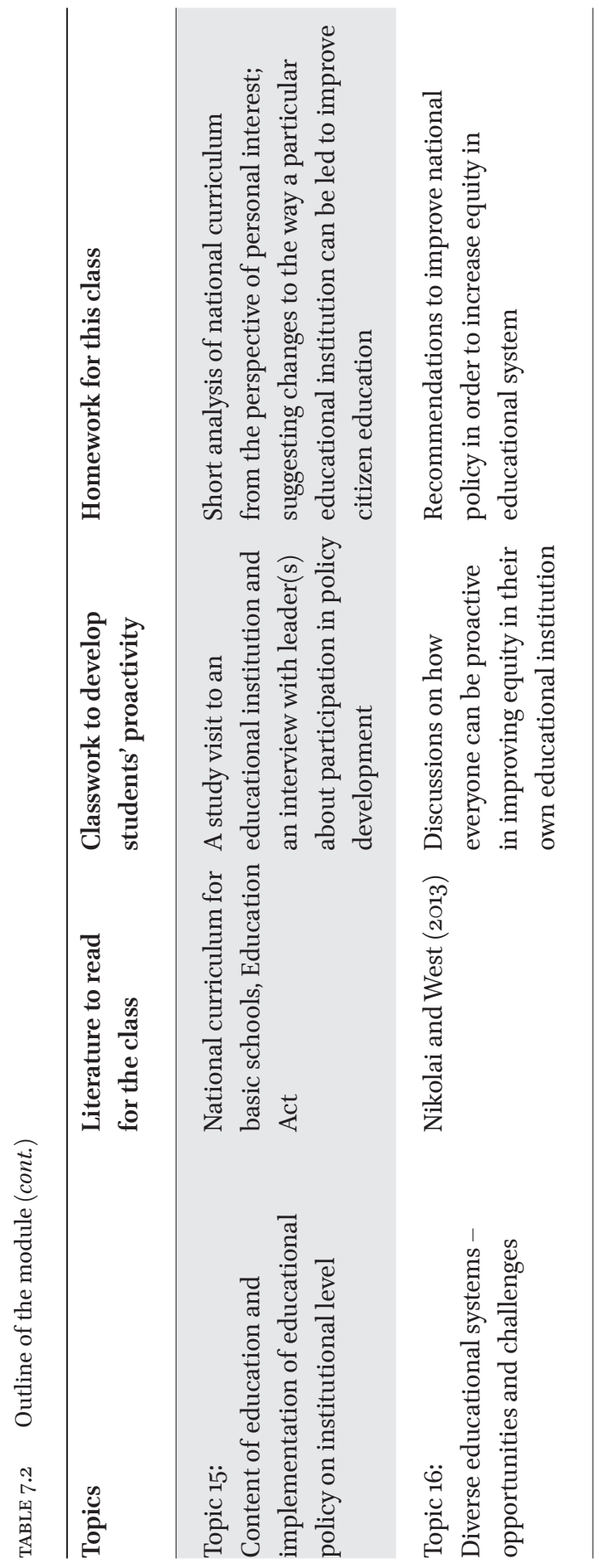


prepare for the class, including site visits, interviews with stakeholders, following related media, etc.

For the final examination, the students write the analysis of one relevant topic of educational policy in their national context, (1) evaluating the impact of this policy to concrete educational institution or learner or to the system in general, (2) describing how different stakeholders/interest groups could be involved in policy development and implementation, and (3) evaluating their personal possibilities to participate in policy debates as active citizens.

In the first try-out year, around 6o students participated, out of whom 5 were international students. Vast majority of Estonian students studied either Educational Management or Early Childhood Education, it was a compulsory course for them. There were also few students from the Subject Teacher MA programme. In the second year, around 70 students participated. Ten students were from Educational Innovation and Leadership programme, which is an international MA programme with international students from Taiwan, Nigeria, Cameron, Russia, Georgia, Bangladesh and Afghanistan.

The second try-out with the bigger group of international students added a whole other dimension - many Estonian students were not aware of the educational situations in the countries some of the foreign students came from. Sharing such knowledge and experience enriched the whole course. It showed in particular when the students presented the works they had to do in a small international group: several groups gave examples of problems or solutions from the perspective of different countries.

Reflection and Future Implications for Improving the Course

After the completion, students gave feedback on the course. They considered the course to be interesting and challenging. The students also found that generally, the course met their expectations and they acquired the learning outcomes of the module; however, some suggestions for improvement were also offered.

Furthermore, critical friends, in the first try-out year Ghazala Bhatti from Bath Spa University and in the second year Elina Kuusisto from the University of Helsinki participated in the course during one day, gave a lecture and also made suggestions. The following reflection and possible improvements to the module are based on students' and critical friend's feedback.

\subsection{Content of the Module}

First, the students are made to think more globally. With reference to global aspects and how they relate to the future educational opportunities for children 
world-wide, it is useful for students to look at the current education systems in different parts of the world, not just in Europe. It means that students will not only be thinking of their own country, but also about the role this country may play in the rest of the world in the future. Today's students must be prepared to take risks and find solutions that present generation has not even begun to imagine. For example, the students learn about a country in Africa or in Asia and to look at the history of the country and the context of their educational challenges. In this way, the students will get familiar with a much broader context and analyse the educational systems from historical and socio-economic perspectives. This means looking at the population, what percentage of boys and girls go to school, what percentage of the population is literate, what are the needs of the society, how many people from that country have migrated to other countries, which social groups these emigrants were from and why did they emigrate. Moreover, taking this wider perspective includes also the analysis the economic side of education, e.g. what percentage of GDP is spent on education - primary, secondary, higher education, etc. - and what is the rate of unemployment and how healthy is the nation (\% of live births in 100). In addition, the work of international organisations like World Health Organisation, United Nations and international agreements like The Dakar Agreement, Salamanca Agreement and the United Nations Charter on the Rights of the Child are be analysed from the perspective of democracy and equality in society.

Secondly, although the module aims to address the three components of democracy - participation, democratic politics, and democratic society (see Veugelers et al., 2017) - these components were not equally covered during the course. There should be several individual works that require the students to analyse their possibilities for participating in debates and policy development, involving different partners and creating open discussion about new educational policy initiatives. Distinction between national and international policy developments is already made in the course, but some more tasks could be added to help the students understand how politics can support creation of democracy and tolerance in society.

Thirdly, this module should develop students' understanding of how to teach values. As mentioned by Veugelers and colleagues (2017, p. 9), there are four ways for teaching values: a specific value-oriented subject; integration of value education into related subjects; cross-curricular activities establishing links with the community; a democratic school culture involving more dialogical methodologies of teaching and learning; and inclusive education bringing together different groups of students and teachers. In addition, although the course elaborated on diversity in school community and shared leadership, these areas could be analysed more deeply on the example of students' personal experiences. 


\subsection{Students' Learning Process}

As it is an intensive course (two months), the students have several individual works in a short time range. As one of the fundamental aims of the programme is to support students' proactive behaviour and willingness to take responsibility, the individual works should be more linked with case studies of everyday problems where students can propose concrete solutions (e.g. how to implement a certain change in their own institutions).

Students mentioned that the course should also allow to improve their everyday practices as teachers or leaders, for example, in developing democracy and opening dialogue at schools. As most of the students are already working in various educational institutions, one task could be to carry out a small-scale action research on how to teach values, e.g. by integrating different subjects or carrying out cross-curricular activities. Another possibility is to observe and collect data about school culture - how inclusion is supported, or how the links with community are established.

The course is also opened for international exchange students. With this, we create an opportunity for the students to enrich their learning and start a dialogue over first-hand experiences of different educational contexts. Although students are encouraged to learn from each other, the process still needs facilitating and support in bridging practical encounterings with theoretical reasons behind them.

As course development is a continuous process, all of the above-mentioned areas of improvement will be considered during the preparation for the next year's course.

\section{References}

Ball, S. J., Maguire, M., \& Braun, A. (2012). How schools do policy: Policy enactments in secondary schools. New York, NY: Routledge.

Bevir, M. (2010). Democratic governance. Princeton, NJ: Princeton University Press.

Busemeyer, M. R., \& Nikolai, R. (2010). Education. In F. G. Castles, S. Leibfried, J. Lewis, H. Obinger, \& C. Pierson (Eds.), The Oxford handbook of the welfare state (pp. 494-508). Oxford: Oxford University Press.

Crossley, M., \& Watson, K. (2003). Comparative and international research in education: Globalisation, context and difference. London \& New York, NY: RoutledgeFalmer.

Di Stasio, V., \& Solga, H. (2017). Education as social policy: An introduction. Journal of European Social Policy, 27(4), 313-319.

Estonian Government. (1996). Eestipõhi-ja keskhariduse riiklik õppekava [Estonian National Curriculum for basic and secondary education]. Retrieved from https://www.riigiteataja.ee/akt/29725 
Estonian Government. (2011a). Põhikooli riiklik õppekava [National Curriculum for basic schools]. Retrieved from https://www.riigiteataja.ee/akt/114012011001

Estonian Government. (2011b). Gümnaasiumi riiklik õppekava [National Curriculum for Gymnasia]. Retrieved from https://www.riigiteataja.ee/akt/114012011002

Estonian Parliament. (1992). Republic of Estonia Education Act. Retrieved from https://www.riigiteataja.ee/en/eli/524042014002/consolide

Feinberg, W. (2012). The idea of a public education. Review of Research in Education, $36(1), 1-22$.

Garritzmann, J. L., Häusermann, S., Palier, B., \& Zollinger, C. (2017). WoPSI-the world politics of social investment: An international research project to explain variance in social investment agendas and social investment reforms across countries and world regions (LIEPP Working Paper No. 64).

Grek, S. (2009). Governing by numbers: The PISA 'effect' in Europe. Journal of Education Policy, 24(1), 23-37.

Harris, A., \& Jones, M. (2015). Transforming education systems: comparative and critical perspectives on school leadership. Asia Pacific Journal of Education, 35(3), 311-318.

Hedtke, R., \& Zimenkova, T. (Eds.).(2013). Education for civic and political participation: A critical approach (Vol. 92). New York, NY \& London: Routledge.

Hood, C. (1991). A public management for all seasons? Public Administration, 69(1), $3^{-19 .}$

Estonian Ministry of Education and Research, Estonian Cooperation Assembly \& Estonian Education Forum. (2014a). Eesti elukestva õppe strateegia 2020 [Estonian Lifelong Learning Strategy 2020]. Retrieved from https://www.hm.ee/sites/default/ files/strateegia2o2o.pdf

Estonian Ministry of Education and Research. (2014b). Haridus-ja teadusministeeriumi arengukava "Tark ja tegus rahvas" 2015-2018 [The development strategy of the Ministry of Education and Research "Wise and active people" 2015-2018]. Tartu. Retrieved from https://www.hm.ee/sites/default/files/tark_ja_tegus_ rahvas_2015_2018_final.pdf

Innove. (2015). Opppijakeskse kooli juhtimine. Juhendmaterjal üldhariduskoolide juhtidele. SA Innove juhitava ESF programm "Üldhariduse pedagoogide kvalifikatsiooni tõstmine 2008-2014" [Leading a student-centred school. Guideline for leaders of general education schools. The Programme of ESF, led by Foundation Innove: "Raising the Qualification of General Education Educators 2008-2014"]. Retrieved from http://www.innove.ee/UserFiles/\%C $3 \% 9$ Cldharidus/

ESF\%2oprogrammid/Juhendmaterjal_2015.pdf

Iversen, T., \& Stephens, J. D. (2008). Partisan politics, the welfare state, and three worlds of human capital formation. Comparative Political Studies, 41(4-5), 6oo-637.

Kitsing, M., \& Peterson, K. (2011). Estonian report. In J. Bolhöfer (Ed.), European synopsis. The making of: Leadership in education (pp. 77-85). Hildesheim: NLQ. Retrieved from http://www.leadership-in-education.eu/index.php?id=27 
Knodel, P., Martens, K., \& Niemann, D. (2013). PISA as an ideational roadmap for policy change: Exploring Germany and England in a comparative perspective. Globalisation, Societies and Education, 11(3), 421-441.

Knowles, R. T., Torney-Purta, J., \& Barber, C. (2018). Enhancing citizenship learning with international comparative research: Analyses of IEA civic education datasets. Citizenship Teaching \& Learning, 13(1), 7-30.

Lauri, T. (2013). School choice as the problem of educational governance in a pluralistic frame. Italian Journal of Sociology of Education, 5(2), 16o-188.

Lauri, T., \& Põder, K. (2013). School choice policy: Seeking to balance educational efficiency and equity. A comparative analysis of 20 European Countries. European Educational Research Journal, 12(4), 534-552.

Lauri, T., Põder, K., \& Rahnu, L. (2017). Challenges facing the Estonian school system:The achievement gap between language-stream schools and school choice of immigrants. In Estonia in the Migration Era. In T. Tammaru, R. Eamets, \& K. Kallas (Eds.), Human development report 2016/2017 (pp. 155-162). Retrieved from https://inimareng.ee/ en/immigration-and-integration/challenges-facing-the-estonian-school-system/

Lipsky, M. (2010). Street-level bureaucracy, 3oth ann. Ed.: dilemmas of the individual in public service. New York, NY: Russell Sage Foundation.

Newman, J., \& Clarke, J. (2009). Publics, politics and power: Remaking the public in public services. London: Sage Publications.

Nikolai, R., \& West, A. (2013). School type and inequality. In R. Brooks, K. Bhopal, \& M. McCormack (Eds.), Contemporary debates in the sociology of education (pp. 57-75). Basingstoke: Palgrave Macmillan.

OECD. (2016a). Global competency for an inclusive world. Retrieved from https://www.oecd.org/education/Global-competency-for-an-inclusive-world.pdf

OECD. (2016b). Trends Shaping Education 2016. Paris: OECD Publishing. Retrieved from http://dx.doi.org/10.1787/trends_edu2o16-en

OECD. (2017). Education at a Glance 2017 (OECD Indicators). Paris. OECD Publishing. Retrieved from http://dx.doi.org/10.1787/eag-2017-en

Rhodes, R. A. (1997). Understanding governance: Policy networks, governance, reflexivity and accountability. Philadephia, PA: Open University Press.

Rissanen, I., Kuusisto, E., Hanhimäki, E., \& Tirri, K. (2018). The implications of teachers' implicit theories for moral education: A case study from Finland. Journal of Moral Education, 47(1), 63-77.

Schütz, G., Ursprung, H. W., \& Wößmann, L. (2008). Education policy and equality of opportunity. Kyklos, 61(2), 279-308.

Solga, H. (2014). Education, economic inequality and the promises of the social investment state. Socio-Economic Review, 12(2), 269-297. 
Stafford-Brizard, K. B. (2016). Nonacademic skills are the necessary foundation for learning. Education Week. Retrieved from http://www.edweek.org/ew/ articles/2016/o7/21/nonacademic-skills-are-the-necessary-foundationfor.html?r=491400431\&cmp=eml-enl-eu-news1-RM\&preview=1\&user acl $=$ o\&intc $=$ es

Steiner-Khamsi, G. (2014). Cross-national policy borrowing: Understanding reception and translation. Asia Pacific Journal of Education, 34(2), 153-167.

Toots, A. (2013). Motivated by education or encouraged by opportunities? A comparative perspective on knowledge and participation nexus. In A. Toots (Ed.), Education for civic and political participation (pp. 107-124). New York, NY: Routledge.

Toots, A., \& Lauri, T. (2015). Institutional and contextual factors of quality in civic and citizenship education: Exploring possibilities of qualitative comparative analysis. Comparative Education, 51(2), 247-275.

Veugelers, W. (2011). Theory and practice of citizenship education: The case of policy, science, and education in the Netherlands. Revista de Educacion, 209-224.

Veugelers, W., De Groot, I., \& Stolk, V. (2017). Research for cult committee - Teaching common values in Europe. Brussels: European Parliament, Policy Department for Structural and Cohesion Policy. Retrieved from http://bit.ly/2 $\mathrm{pm}_{5}$ Yhy

World Economic Forum. (2016). The future of jobs. Employment, skills and workforce strategy for the fourth industrial revolution. Retrieved from http://reports.weforum.org/future-of-jobs-2016/ 